\title{
SALT LAKES OF THE WEST KAZAKHSTAN REGION AS OBJECTS OF MEDICAL TOURISM
}

\author{
Kazhmurat M. AKHMEDENOV* \\ M. Utemisov West Kazakhstan University, Department of Geography, Uralsk, Kazakhstan, e-mail: kazhmurat78@mail.ru
}

Rysty A. KHALELOVA

Lomonosov Moscow State University, Department of Environmental Management, Moscow, Russian Federation, e-mail: rkhalelova@bk.ru

\begin{abstract}
Citation: Akhmedenov, K.M., \& Khalelova, R.A. (2021). SALT LAKES OF THE WEST KAZAKHSTAN REGION AS OBJECTS OF MEDICAL TOURISM. GeoJournal of Tourism and Geosites, 36(2spl), 637-645. https://doi.org/10.30892/gtg.362spl11-693
\end{abstract}

\begin{abstract}
West Kazakhstan region is also rich in unique balneological hydromineral resources. The aim of the study was to review the studied, as well as little-known and promising, salt lakes of West Kazakhstan region, which have hydromineral resources suitable for balneological and recreational use is given. As a result of the field and laboratory researches in 2017-2020, 7 promising balneological sites were studied - the Lakes Bolshoy Sor, the Alzhansor, the Sorkol, the Hakisor, the Aralsor, the Edilbaysor, the Koysarysor. It was established that the studied peloids correspond to the genetic type of mainland silt mineral (sulphide) therapeutic mud typical of arid regions. According to the main indicators, the studied peloids are generally suitable for use in recreational, therapeutic and medical purposes, and in terms of the content of salts and therapeutically valuable components, they are not inferior to the medical mud of the resorts of Western Kazakhstan and the Dead Sea recognized in balneological practice.
\end{abstract}

Key words: salt lakes, therapeutic mud, peloid, tourism, balneology, physicochemical properties, West Kazakhstan region

\section{INTRODUCTION}

In the modern world, peloids are actively studied and used for various purposes. The scientific community is discussing a single concept and classification of peloids (Gomes et al., 2013), as well as the advantages and risks of using therapeutic clays for therapeutic and cosmetic purposes (Gomes, 2018), many works are devoted to the unique black hypersaline mud mined on the shores of the Dead Sea (Nissenbaum et al., 2002; Ma'or et al., 2005) investigate the features of natural peloids (Gomes et al., 2015) and the use of local natural thermal mud for therapeutic, aesthetic and pharmaceutical purposes (Karakaya et al., 2010). The chemical composition of therapeutic mud is investigated (Doretti et al., 1992; Bokuchava, 2009; Solonenko, 2015; Tserenkhand and Badnainyambuu, 2016; Díaz Rizo et al., 2018; Gupta et al., 2018; Bolshoiovic et al., 2020) and the influence of human society on the composition of peloids of modern salty lakes (coastal zones of the Black, Azov and Dead Seas) (Kotov et al., 2019). Mud making in the territory of modern Kazakhstan was known in the XIII century. The first works on the healing properties of therapeutic mud were published in Russia in the XVIII-XIX centuries. From the middle of the XX century a comprehensive study of therapeutic mud began. In Kazakhstan, the hydromineral resources of Lake Zhalanashkol (Tokpanov, 2016), deposits of sulphide therapeutic mud of the lakes Zhaman, Minkeser, Kishkenesor, Karasor of the North Kazakhstan region (Fomin et al., 2012) and therapeutic mud of lakes Arasan-Kundyzdy, Tuzkol, in Almaty region (Kan et al., 2019) were investigated. Also, Kazakhstan has a large number of deposits of therapeutic mud: Tuzkol (Almaty region); Zhasybay, Alamergen (Pavlodar region); Borsykty, Sorkol, Aksuatsor (Kostanay region); Karasor (Karaganda region); Karabulakkol (East Kazakhstan region), etc. (Dzhangeldina and Ospanova, 2017). Salt lakes are widespread on the leftbank part of the Irtysh River (Lake Kalkamanskoye, Lake Kishken-Tuz, etc.) (Belgibaev and Zhaparova, 2020).

In Almaty region, the physicochemical properties of cover waters (rapa) and therapeutic mud of Lake Zhalanashkol were studied, during laboratory studies it was found that the cover waters (rapa) of the lake is of the type sulphate-chloride-sodium (Asubaev and Esmseitova, 2015). Modern mud resorts of Kazakhstan include Moyyldy (Pavlodar region), Zhanakorgan (Kyzylorda region), Atyrau (Atyrau region), Shchuchinsky (Akmola region), Saryagash (South Kazakhstan region), Akzhayyk (West Kazakhstan region) and others where local resources are actively used in the treatment of many diseases.

West Kazakhstan region is also rich in unique balneological hydromineral resources. Among them, the healing mud of salty lakes, which in recent years has been actively studied by us, stands out (Akhmedenov, 2018; Akhmedenov, 2020a; Khalelova et al.,2020). In the West Kazakhstan region, there are more than 7.000 large and small lakes with a total area of over 29.8 thousand $\mathrm{km}^{2}$, most of which are dense and extremely small. The area of their water mirror, usually, does not exceed $1 \mathrm{~km}^{2}$ (Filonec and Omarov, 1974; Baisholanov et al., 2017). The origin of many lakes in the region is associated with the processes of halokinesis and spatial transfer of salts by groundwater within the borders of the Caspian salt-dome basin (Sotnikov et al., 1971; Filonec and Omarov, 1974). Kazakhstan is actively developing research on various aspects of tourism (Wendt, 2020). A number of studies have been conducted to assess the natural and recreational potential of West Kazakhstan region (Akhmedenov, 2020b; Koshim et al., 2020; Chashina et al., 2020). The purpose of our study is to assess the possibilities of using salty lakes of West Kazakhstan region for the development of medical tourism.

\footnotetext{
* Corresponding author
} 


\section{MATERIALS AND METHODS}

In West Kazakhstan region, accumulative plains of marine origin associated with the era of maximum Khvalyn transgression prevail within the Caspian lowland (Doskach, 1956). Their flat-wavy surface is complicated by a large number of shallow dryless westerns and weakly cut channels of temporary rivers and a duct opening into flat, more often elongated lakeshaped depressions. In summer, ducts and lake-like depressions partially or completely dry out, forming salty lakes known as burrows. The locations of many sorrows are due to the latest tectonic movements, which manifested themselves either in the formation of regional zones of tectonic deflections (large saline depressions), or caused by salt tectonics (bursts confined to inter-dome depressions, compensatory mulds and sedimentation mulds). Among the latter, lake depressions stand out, associated with the especially active latest deflection of depressed compensatory mules, complicating the salt massifs of actively growing domes (Lake Baskunchak, Inder, Elton, etc.). Compensatory mulds, which were actively bending in modern times, correspond to lakes Elton, Baskunchak, Inder, Shalkar, Zhaltyrkol. Many smaller lakes and burrows correspond to the grabs of domes and mulds of subsidence, active in modern times (Sidorenko, 1970).

Sors (a local name of saline) are also found in the sandy massifs of West Kazakhstan region, they are widespread, and their number increases from north to south, that is, towards the Caspian Sea (Badyukova, 2020). In the northern part of the sands, the greatest distribution of saline is observed in the area of the Kamysh-Samara Lakes, Lake Aralsor and the mud of Khaki. In the southern part, a significant number of burrows are noted around major depressions (Dongelek-Sor, Bolshoi Sholan) and hills (Beschoky, Koshalakty, Myntyube), but at the same time they are found everywhere among various sands and soils. In most cases, quarries have an elongated shape and in orientation obey mainly the general slope of the area (Badyukova, 2020). The size of the weeds is very diverse and varies from a fraction of a 0.01 to $0.5 \mathrm{~km}^{2}$. The width of the elongated pile ranges from tens of meters to 200-300 meters, and the length reaches 1-2 km (Badyukova, 2020).

Depending on the degree of replenishment of lakes with spring fresh water and on the meteorological conditions of the year, the degree of mineralization of water in lakes varies, but they usually have brackish or salty water (Kamensky et al., 1960). Deposits of saline with a thickness of 0.5 to 4 meters are expressed in silt sands, sandy loam and loam with gypsum crystals. Often there is an alternation of silt sands and sandy loam. In these deposits, overfished plant remains are observed, so they have a sharp smell of hydrogen sulphide (Kamensky et al., 1960).

The collection of materials on the study of the modern state of the salty lakes of West Kazakhstan region was carried out in 2017-2020. The study was carried out using the following methods: literary and cartographic, comparative-historical. As a result of the field and laboratory researches in 2017-2020 7 promising balneological sites were studied - the Lakes Bolshoy Sor, the Alzhansor, the Sorkol, the Hakisor, the Aralsor, the Edilbaysor, the Koysarysor (Figure 1).

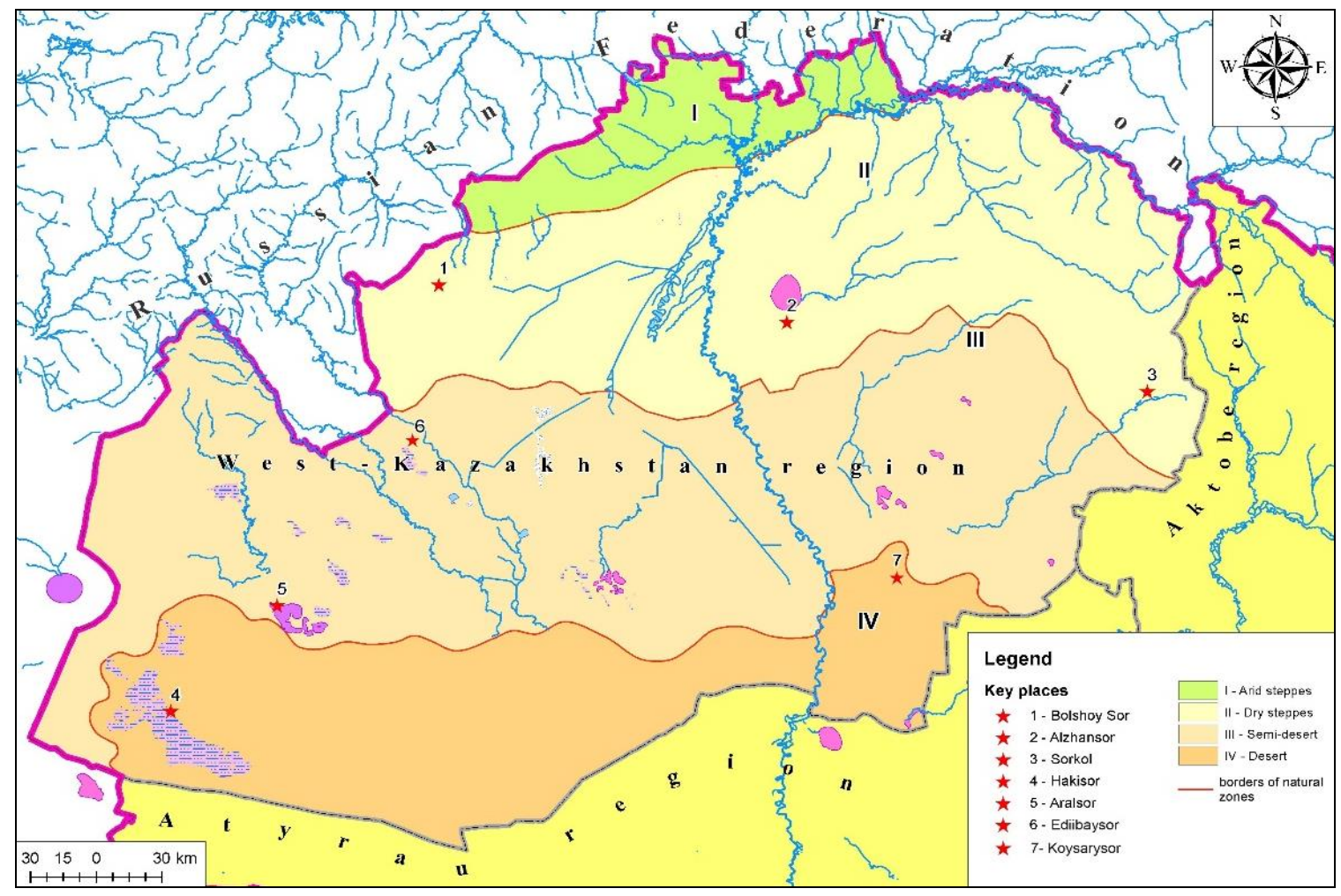

Figure 1. Location of the studied salt lakes West-Kazakhstan region

During the field study, key salty lakes with therapeutic mud were identified, and their description was carried out. Littlestudied salty lakes Hakisor, Alzhansor, Bolshoy Sor, Sorkol basins of which are genetically associated with mulds of sedimentation of salt domes were chosen as research objects for assessing the balneological value of peloids. In physical and geographical terms, they belong to the desert-steppe regions of the Caspian (Volga-Ural) desert-semi-desert region (Kopyl and Nikolaev, 1984). According to hydroecological conditions, they are attributed to the Zhaiyk-Zhemsky hydroecological district, 
the total area of which is 772.8 thousand $\mathrm{km}^{2}$, and the lake area is $0.25-0.50 \%$ (Medeu et al., 2010). To conduct a full range of physical and chemical analyses and a primary assessment of the balneological properties of the peloids of the lakes Hakisor, Alzhansor, Bolshoy Sor, Sorkol during the spring-summer season 2017-2020, samples of peloids from mud deposits and samples of cover waters (raps) of lakes were selected. Sampling was carried out according to accepted techniques (Bahman et al., 1965; Mikheeva and Trebukhov, 1975) with fixation in place: a) parameters of the reservoir and sampling conditions (name of the reservoir, temperature of air and water, date and place/coordinates of sampling, depth of sampling, capacity of the mud deposit, height of the rapeseed layer above the surface of the mud deposit); b) organoleptic indices of dirt samples (color, smell, consistency, structure); c) presence and nature of inclusions (salt crystals, sand, plant residues).

For assessment of balneological value of peloid laboratory analyses of their main physical and chemical properties and content of heavy metals, toxic for the person, which were made in the accredited testing laboratory of chemical analysis researches of U.M. Akhmedsafin Institute of hydrogeology and geoecology (Almaty, the Republic of Kazakhstan) according to the accepted techniques of studying therapeutic muds and carrying out physical and chemical analyses (Bahman et al., 1965; Mikheeva and Trebukhov, 1975; Radulescu et al., 2014). The obtained data (Table 1) were compared with regulatory requirements for the quality of therapeutic mud (Mikheeva and Trebukhov, 1987; Adilov et al., 2000), and published data on exploited peloid deposits, including the Dead Sea (Nissenbaum, 2002; Myazina, 2013; Belenitskaya, 2013; Kotova et al., 2015; Lopatina, 2016; Dikke, 2016; Kovtun, 2017; Malkhazova et al., 2019; Kalioujnaia et al., 2019; Akhmedenov, 2020a).

The study of hydromineral resources is closely related to the problem of determining the need to determine the degree of their suitability for the development of health and ethnographic tourism. To this end, numerous published research materials carried out in the territory under consideration in different years were used. Based on the generalization of hydrogeological, geomorphological and geoecological materials on the state of salt lakes, as a result of expeditionary and laboratory studies, we established differences and similarities in the chemical composition of water and therapeutic mud, and assessed the recreational potential of salt lakes in West Kazakhstan region.

\section{RESULTS AND DISCUSSION}

Based on the analysis of literary sources and survey data, 40 salt lakes with natural accumulations of therapeutic mud and healing water were allocated in the West Kazakhstan region (Sdykov et al., 2010):

- in Shyngyrlau district there are 3 lakes: Akkol, Sorkol, Kindikty;

- There are 7 lakes in the Syrym region: Aydar, Ashy, Zhangabylsor, Esentemir, Aybar, Dongelexor, Tuzsay;

- in Taskalinsky district there are 2 lakes: Bolshoy Sor, Nurlybaisor;

- in Terektinsky district 1 lake: Alzhansor;

- 7 lakes in Akzhayyk region: Tuzdykol, Zhienbaysor, Baigutty, Koltai, Aralsor, Zhaltyrkol, Koisary;

- in Zhangalinsky district there are 3 lakes: Sorkol, Sarykol, Maly Kyzyloba;

- There are 11 lakes in the Kaztalov region: Araltobe, Batpak, Bayar, Edilbaysor (Bolshoi and Maly Sakryl), Shoityn, Akkol, Kazbek sor, Zhalpak, Kamystykol, Turkesor, Tagaysor;

- in Bokeyorda district there are 4 lakes: Aralsor, Batpak, Hakisor, Botkul;

- in Karatobinsky district 1 lake: Zhibexsor.

For a more detailed study, we have chosen 4 lakes: Alzhansor, Bolshoy Sor, Sorkol, Hakisor. One of the criteria for assessing the balneological properties of therapeutic mud is their chemical composition. Therefore, we conducted a study of the chemical nature of the mud of the salty lakes of West Kazakhstan region. The results of the studies were compared with the Dead Sea peloids (Table 1, Figure 2 and 3). A study of some lakes in West Kazakhstan region showed that the composition of their therapeutic mud is not inferior to the quality of the healing mud of the Dead Sea. The Dead Sea is a deep-sea saline basin corresponding to a tectonic lake located in a shear-type structure within the Afro-Arabian inner-intercontinental folding belt (Belenitskaya, 2013). Comparative results of analysis of basic physicochemical properties of Dead Sea peloids and lakes of West Kazakhstan region determining their balneological value are presented in Table 1.

Table 1. The main physicochemical parameters of the peloids of the WKO lakes and the Dead Sea Data source: (personal original data, and also Lopatina, 2016; Dikke, 2016; Kovtun, 2017; Adilov et al., 2000)

\begin{tabular}{|l|c|c|c|c|c|}
\hline \multicolumn{1}{|c|}{ Indicators and standard } & The Dead Sea & Alzhansor & Bolshoy Sor & Sorkol & Hakisor \\
\hline Humidity, 25-75 & 37.17 & 47.3 & 40.1 & 27.9 & 23.1 \\
\hline Volume weight, $\mathrm{g} / \mathrm{cm}^{3}, 1.1-2.0$ & 1.77 & 1.47 & 1.65 & 1.88 & 1.80 \\
\hline Shear resistance, dyne / cm ${ }^{2}, 1500-4000$ & 1153 & 4090 & 3196 & 1990 & 31500 \\
\hline Particle contamination 0.25-5.00 mm, <3.0 & 0.03 & 1.4 & 1.06 & 20.7 & 0.2 \\
\hline Mineral inclusions with a size of $>5.0 \mathrm{~mm}, \mathrm{no}$ & $\mathrm{absent}$ & sand, plant residues & absent & sand, small stones & absent \\
\hline $\mathrm{pH}, 7.0-9.0$ & 5.7 & 7.97 & 7.11 & 8.39 & 7.21 \\
\hline Oxidation-reduction potential, Eh, mb -500-0 & +230 & +310 & +214 & +394 & +112 \\
\hline Heat capacity, cal / g. hail, 0.4-0.8 & 0.497 & 0.579 & 0.521 & 0.423 & 0.385 \\
\hline Iron sulphides, \% for wet mud, not less than 0.01 & 0.04 & 0.1 & $<0.1$ & $<0.1$ & 0.2 \\
\hline Mineralization of mud solution, g / dm 3 , >150 & 320.7 & 152 & 124 & 195 & 160 \\
\hline Bromine, mg / dm & 5985 & 1043 & 1238 & 1394 & 1208 \\
\hline Boric acid, mg / dm 3 & 163 & 8.10 & 3.00 & 23,60 & 8.90 \\
\hline
\end{tabular}

Humidity, volumetric weight and shear resistance of the Dead Sea peloids and the considered lakes of the West Kazakhstan region, which determine the viscous plastic properties of the peloids, are within the normative values (Table 1), 
which allows them to be used in their natural form, without preliminary liquefaction. High heat capacity values allow mud to accumulate a fairly large amount of energy during heating and contribute to a slow heat release during balneoprocessing. The $\mathrm{pH}$ value and negative redox potential characterize the peloids as a substrate in which reducing processes take place. According to the totality of the main physicochemical indicators, the peloids of the Dead Sea and lakes of West Kazakhstan region meet the criteria for the suitability of silt sulphide mud for medical procedures.

Peloids lake Sorkol for most physicochemical indicators also meet the criteria for the suitability of silt sulphide mud. However, the high degree of clogging of samples lake Sorkol $(20.7 \%)$ with mineral particles with a diameter of $0.25-5.0 \mathrm{~mm}$ reduces the plastic properties of dirt, and the presence of solid mineral inclusions larger than $5 \mathrm{~mm}$ can lead to damage to the skin during balneoprocedure. Therefore, before use they must be brought to the appropriate regulatory parameters by pretreatment on vibrosites to remove sand and fine stones, as well as by dissolving crystals of salts with fresh water, while maintaining the recommended humidity values (25-75\%) (Mikheeva and Trebukhov, 1987; Zhuravleva, 2008). The main therapeutically valuable components of lake peloids are water-soluble salts, sulphides and hydrogen sulphide, as well as a number of trace elements - bromine, boron and iodine. The largest content of bromine and boric acid is observed in Lake Sorkol $\left(1394 \mathrm{mg} / \mathrm{dm}\right.$ and $\left.23.60 \mathrm{mg} / \mathrm{dm}^{3}\right)$, which is more comparable to the Dead Sea. Dead Sea mud is characterized by the lowest sulphur content $(0.4-0.8 \%)$ compared to West Kazakhstan region lakes (10-44\%), as well as the highest calcium content (9-13\% against the background of 0.7-2.6\% in the mud of West Kazakhstan region lakes). Only lake Bolshoy Sor in terms of calcium content (14\%) is comparable to the Dead Sea. The amount of chlorine in the mud of all West Kazakhstan region lakes varies from 55 to 97\%, which exceeds the chlorine content in the Dead Sea (5-10\%) (Kotova et al., 2015).

Obviously, the relatively low sulphur content is due to the small amount of sulphates in the mud of the Dead Sea, which is consistent with the established mineral-salt type of these mud - chloride-carbonate; it is believed that it was the apparent predominance of carbonates in the mud of the Dead Sea that caused a relatively high calcium content in their composition (Nikanorov, 2001). At the same time, the mineralization of the peloids lakes Karabatan and Sorkol are significantly higher than the rest of the lakes of Western Kazakhstan (Nikanorov, 2001) (Figure 2).
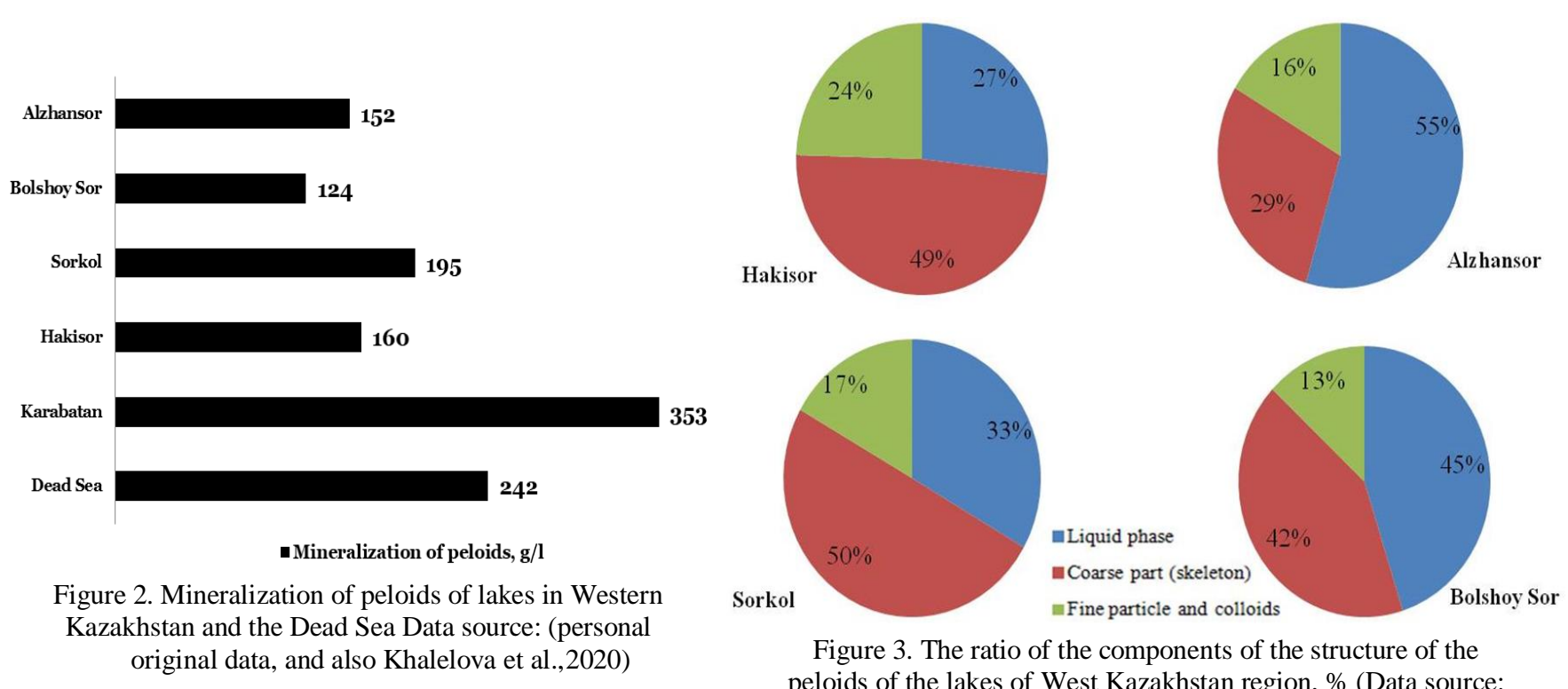

Figure 3. The ratio of the components of the structure of the peloids of the lakes of West Kazakhstan region, \% (Data source: personal original data, and also Khalelova et al., 2020)

In terms of ionic composition and mineralization, the peloids and cover waters (rapa) of the lakes of Western Kazakhstan are fairly typical strong brines - chloride-sulphate sodium (Sorkol, Hakisor) and chloride sodium-magnesium (Bolshoy Sor, Alzhansor), sulphate-chloride-sodium. The ratio of three interconnected components of the structure of peloids - the liquid part, the coarse-dispersed part (backbone) and the colloidal complex, is also one of the indicators determining the balneological value of mud (Olefirenko, 1986; Zhuravleva, 2008; Muradov, 2014; Fedotchenko, 2010). The analysis showed that the peloids of lakes have great skeletal strength and a high content of liquid fraction (Figure 3 ).

Sufficient saturation with the colloidal complex (Hakisor 24\% and Sorkol 17\%) determines the good plasticity of mud, its moisture intensity and thermal properties (Khalelova et al., 2020). At the same time, in the skeleton of the peloids Lake Sorkol and Hakisor there is a high content of calcium carbonates $(23.5 \%)$ and (2\%), respectively, and in the skeleton of the peloids oz. Alzhansor, Bolshoy Sor - a significant amount of gypsum (6.3\%) and (12.5\%), which can negatively affect the viscoplastic properties of mud. Among the peloids we studied, there was a high content of organic substances in Lake Bolshoy Sor $(2.09 \%)$ and Sorkol (1.58\%), Alzhansor (1.40\%), the smallest in Lake Hakisor $(0.19 \%)$. These indicators are higher than in the mud of the Dead Sea, but there is a similarity with the continental sticky hydrosulphide peloids of Mongolia. In the salt lakes of Mongolia, the concentration of total organic carbon in all continental sticky hydrosulphide peloids is 0.4 to $3.1 \%$ (Tserenpil et al., 2010). For our region, the therapeutic value of the studied peloids is enhanced by the presence of organic substances in them, due to the activities of galobiont microorganisms (gill-legged crustaceans Artemia salina) found in samples, enriching dirt with biostimulants (humic substances, enzymes, vitamins, hormones, etc.). The 
solution squeezed from such mud can be used as an independent treatment agent in the form of compresses, lotions, rinses and other procedures, as well as for the production of drugs and cosmetics (Khalelova et al., 2020).

In general, the mud of West Kazakhstan region lakes is characterized by higher organic content compared to the Dead Sea. Thus, our results suggest that the presence of known bioactive organic compounds such as humic acids, lipids and carbohydrates, as well as hydrogen sulphide, increases the balneological value of the peloids of West Kazakhstan region.

All of the above mentioned components are balneologically significant and have beneficial effects in the treatment of musculoskeletal system, cardiovascular system and other diseases. Lakes are popular and in summer tourists come here in large numbers to take medical and recreational procedures. From the point of view of medical recreation, the chemical properties of lake waters are of particular interest. The medicinal importance of lakes consists of many factors, and above all, depends on the composition and content of salts in their waters and the characteristics of therapeutic mud. It is well known that swimming in salt water in combination with air-solar procedures has a healthy and generally strengthening effect on vacationers, which attracts tourists to the salt lakes of West Kazakhstan region. At the same time, our research has made it possible to solve a number of independent, equally important issues related to the assessment of the prospects for using the therapeutic mud of the salt lake for tourist and recreational purposes. We have evaluated promising salt lakes with silt mud for recreational and tourist use, these are lakes Hakisor, Alzhansor, Edilbaysor, Koysarysor (Figure 4).

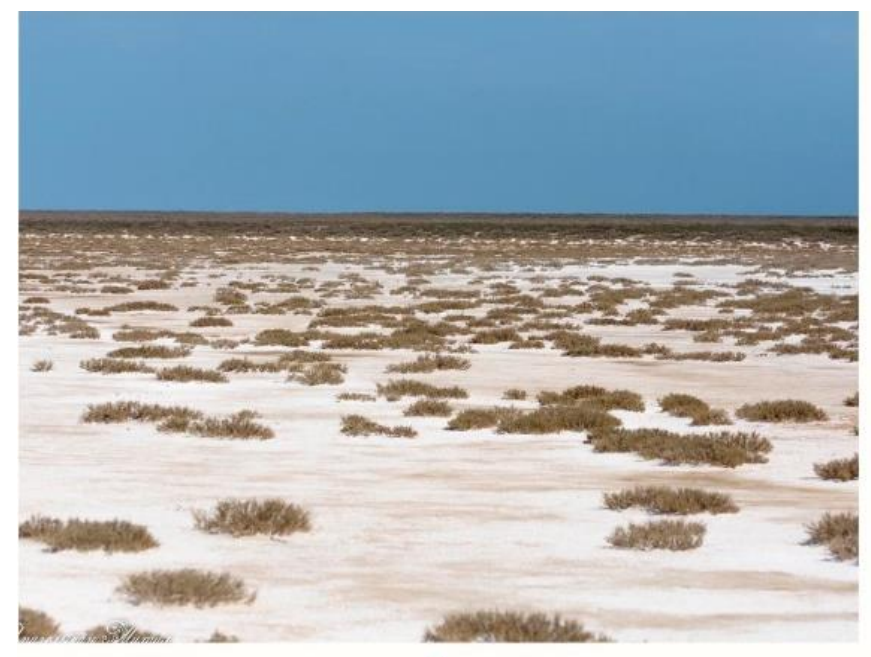

A

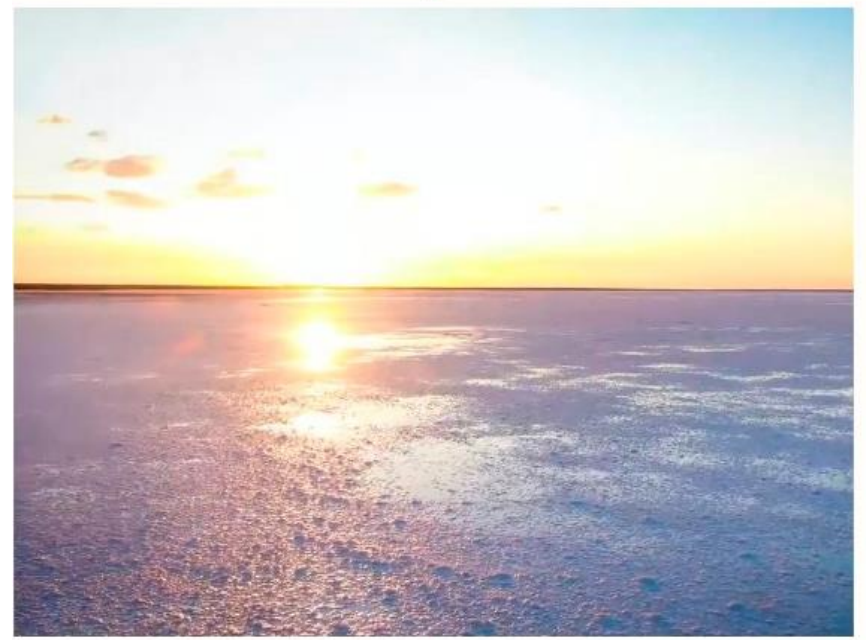

C

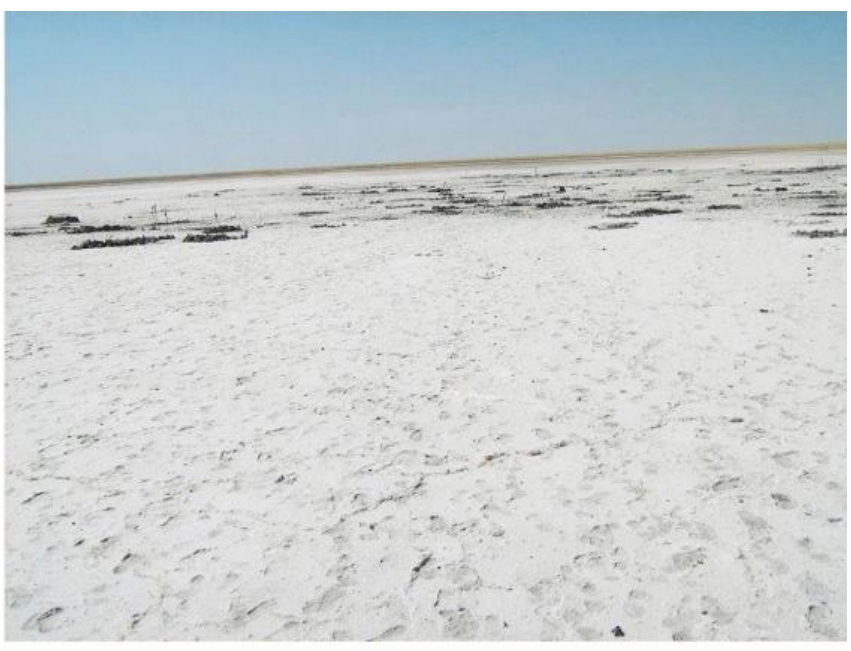

B

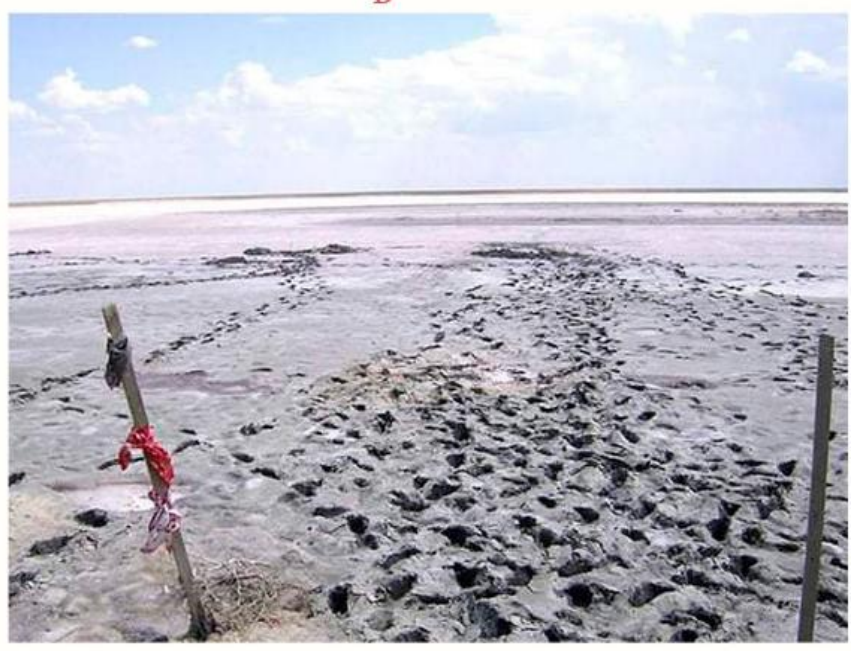

D

Figure 4. Perspective balneological salt lakes of West Kazakhstan region: A - a general view of Lake Hakisor;

B - a general view of Lake Alzhansor; C - a general view of Lake Edilbaysor; D - a general view of Lake Koysarysor

Lake Hakisor is located in the Bokeyordinsky district of the West Kazakhstan region and represents the final phases of the lakes die-off in an arid climate - the phase of salty mud, periodically and not completely covered by a thin layer of cover waters (rapa). Hakisor is one of the largest salt marshes in the world, covering an area of more than 1000 square kilometers (Figure 4). In length, this saline reaches $80 \mathrm{~km}$, its width is $15-25 \mathrm{~km}$, and the depth of the depression containing it is more than $15 \mathrm{~m}$ (Abaturov and Konyushkova, 2020). The surface of Hakisor is covered with a thin crust of salt 0.3-3 $\mathrm{cm}$ thick, under which saline clay deposits lie. In spring, the surface of Hakisor is covered with a thin layer of cover waters (rapa), which in summer is preserved only in micro-depressions (Abaturov and Konyushkova, 2020).

Lake Alzhansor is located on the territory of the Terektinsky district of the West Kazakhstan region, $22 \mathrm{~km}$ south of Lake Shalkar, $15 \mathrm{~km}$ northwest of the Kuralysay village, $110 \mathrm{~km}$ southeast of the Akzhayyk sanatorium and $10 \mathrm{~km}$ east of 
the Duana village. The area of the lake is 0.2 square kilometers. The lake is included in the list of objects of the state nature reserve fund of republican significance by Decree of the Government of the Republic of Kazakhstan No. 932 dated September 28, 2006. The banks are steep, their height is from 2 to 5-7 m (Figure 4). By origin, the salt-domed negative structure. In the north-eastern part of the lake flows a small drying river, which is fenced with dams.

The lake has balneological significance, the local population considers it a holy place. Edilbaysor has a mineral aquifer covering an area of 5.5 square kilometers (Figure 4). Mud and water have healing properties and used for the treatment of joint diseases. According to legend, in the 19 century in this lake for three days Zhangir Khan (khan of the Bukeyev horde $(1823-1845))$ took medical procedures, arriving on the lake on three pairs of horse carts. In Kaztalov and Zhanazhol rural districts where the salt lake is located a large number of people from the eponymous genus "Edilbay" live and breed sheep of the Edilbay breed. On the watershed of the Karaozen and Saryozen rivers there are two salty lakes - the Bolshoy Salty Sakryl and the Maly Salty Sakryl. They are known from the local population called Edilbaysor and are huge dried closed salty basins filled only with melted spring waters. For most of the year, salt water is kept only isolated from each other by small areas. Lake Bolshoy Sakryl is located $30 \mathrm{~km}$ northwest of the village of Zhalpaktal. Maly Sakryl is located half a kilometer south of Bolshoy Sakryl. The area of Lake Bolshoy Sakryl is 260 square kilometers, Lake Maly Sakryl - 70 square kilometers. At the bottom of the Bolshoy Sakryl there are several gas-bearing springs, the mud of which is considered high-healing by the local population (Ivanov, 1951). A series of gas springs is located in the south-eastern part of the lake on a peninsula stretched parallel to the shore and connected to it by a narrow isthmus.

Lake Koysarysor (Figure 4) is located $8 \mathrm{~km}$ north of the Zhamankuduk village of Bazarsholansky rural region, Akzhaik district, West Kazakhstan region. Nearby is the necropolis of Koysary Aulie, where the Koisary batyr from the Kazakh clan Alash is buried. On the old Soviet map it was marked as "Karagaimola". According to legends, earlier Koysarysor was a freshwater reservoir. Before Koysary's death, the batyr told descendants that after his death, this lake would turn into salty weed, and his dirt would treat the sick. The place is revered as holy and in 2006 one of the descendants of Koysary batyr built a mausoleum of red brick. In West Kazakhstan region, the national tradition of using salty lakes has been preserved. In the West Kazakhstan region, July-August months are called the "salt month." This is the time to "plunge" into the healing black mud of a salty lake and get treatment. There are many such healing places in the region. Traces of their spontaneous use for self-treatment in salt lakes are found almost everywhere. But, unfortunately, its civilized use, the creation of modern health facilities and public service are not established. At the height of the year, which the Kazakhs call "forty days of July," the older generation gathered on a salt lake to adopt medical procedures. Almost every salty lake has a saint protecting this healing place. There are special rituals for the use of salty lakes for medicinal purposes. At first they visited the burial place (grave) of the saint, prayed and tied nodules of white cloth with coins at the grave of the saint. Then, a yurt was placed on the shore of a salty lake and cattle were slaughtered. While women care for the hearth boiler, men dig a "well" with a wide top and a narrow bottom near the shore of the salty lake. A little later, the bitterly salty water of the lake begins to accumulate to the bottom of the pit. This water is needed to wash away healing mud. And pits with healing mud are dug closer to the center of the lake 10-15 meters from the shore of the lake. You can't swim in salt on a hungry stomach.

The time of treatment mud is also limited, lasting no more than one hour. Then they completely wash the salt water of the lake and dress densely. More often, procedures with therapeutic mud are taken three times at certain intervals. In the break between procedures, you need to drink hot tea and lamb broth. The main condition is not to wash up to three days after the adoption of procedures. Dress tightly, avoid wind and cold. These days, human skin is especially softened, often sweating, salt is absorbed into the skin and the surface of human skin remains white. Only three days later, a person completely washes up with clean water and changes clothes. Leaving such a "sanatorium" people tie a handkerchief with a monetary trifle, a multiple of 7 - for good luck. Each year, a person who had undergone such treatment was cleared of skin diseases and drove away the cold accumulated in the joint. We can say that the centuries-old traditions and customs of using healing mud and salts remain unchanged. Salty lakes of West Kazakhstan region are far from classic tourist places.

Salt lakes attract many visitors, who are mainly attracted to the healing properties of salt water and mud. For the development of tourism on the salty lakes of West Kazakhstan region various options for tourism can be combined (environmental tourism, ethnographic tourism, gastronomic tourism, health tourism). It is possible to develop ecological trails using medical procedures. To organize one-day and three-day tours. Along the coast of the lakes establish stands with information about the lake and legends about its origin. To place visit centers, put Kazakh yurt, place structures with rooms - shower, toilet and locker room. Developing an ecological trail, it is possible to imagine Kazakh culture here, this is a free niche in the market of tourist services in West Kazakhstan region, this idea should be in demand. One of the main problems is the remoteness of objects from civilization and off-road. But this can also be used as an advantage by organizing jeep tours - trips to salty lakes on off-road. At the same time, it is not necessary to build expensive fashionable hotels with helpful staff or sanatoriums, although this can be organized on some large lakes. West Kazakhstan region salt lakes are not inferior in medicinal properties to world sights, like the salt lake Uyuni in Bolivia, the Dead Sea in Jordan, the hot spring Kangal in Turkey and the Blue Lagoon in Iceland (Atkinson, 2007; Kotova et al., 2015; Ozer et al., 1987; De Almeida, 2018).

We consider ethnographic tourism as one of the possible strategic directions for preserving and developing the economy of traditional agriculture, contributing to the preservation of natural and historical and cultural heritage and is a factor in the sustainable development of territories. The Kazakh people are the bearers of a unique culture and economic system, therefore, the development of ethnographic tourism is promising in conjunction with the development of ecological and recreational tourism in West Kazakhstan region. Despite the presence of salty lakes in the West Kazakhstan region, they do not have official medical reports for use, except Lake Alzhansor. According to a medical report issued on 29 May 2014 by the Research Institute of Cardiology and Internal Diseases (Almaty), the mud of Lake Alzhansor belongs to highly mineralized medium- 
sulphide silt mud with operational reserves of therapeutic peloids of 1-5 thousand cubic meters per year. The hydrological system of salt lakes and their surroundings is extremely vulnerable to climate change and human intervention, but available local and regional information is scarce. Examples of negative changes in salt lakes during their irrational use are known.

For example, Lake Elton [ $49^{\circ} 08^{\prime} \mathrm{N} 46^{\circ} 42^{\prime} \mathrm{E}$ ] in Russia with a surface area of 155 square kilometers and salt water with a salt concentration of 300 grams per liter is known as one of the largest and most salty inland lakes in Europe. After the high water flooded the Elton health resort on the lake in 2005, dams were constructed to prevent future floods and mudflows. However, the resort uses mineral-rich mud to treat skin diseases, and dams seem to threaten the existence of mud, reducing the amount of sediment entering the lake (Argaman et al., 2012). Therefore, it is very important to understand the hydrological system before interfering and dramatically changing the dynamics of a fragile system, such as a salt lake.

\section{CONCLUSION}

1. The origin and basic properties of the peloids of the studied lakes correspond to the genetic type of mainland silt mineral (sulphide) therapeutic mud typical of arid regions. According to the composition, the main organoleptic and physicochemical indicators, the absence of heavy metals and the peloids of the salty lakes of West Kazakhstan region as a whole meet the criteria for the suitability of silt sulphide mud for medical procedures.

2. Own deposits of therapeutic mud served as the basis for the development of health tourism. However, the unique natural healing resources, which ensure the high efficiency of treatment of most diseases and recovery of the population, have not yet been properly used. In this regard, the need for a comprehensive study of the peloids of the salt lakes of Kazakhstan with the prospect of building balneological centers is ripe. Salty lakes of West Kazakhstan region have potential for their use in health and ethnographic tourism.

3. Currently, the most famous and curative reservoirs in West Kazakhstan region are salt reservoirs - this is Lake Alzhansor, the therapeutic mud of which is already used in local sanatoriums. Other lakes the Bolshoi Sor, the Sorkol, the Hakisor, the Edilbaysor and the Koysarysor listed above are less popular and little mastered, although they have balneological properties, and therefore they are promising for use in medical and recreational purposes.

4. As a result of the work done, it is recommended to organize recreational complexes for tourists who rest without trips for the purpose of tourist and recreational use of salt lakes. With appropriate engineering improvements, the recreational potential of the lakes will increase significantly. At the first stage of the work, it is necessary to create summer towns in a tent, light prefabricated version; arrangement of tent sites; construction of sanitary units and waste collectors; accommodation of trading tents-pavilions. In the next stages - the construction of tourist centers, holiday homes for families with children, campsites, etc. For organizational works it is necessary to conduct a survey of the recreational resources of salt lakes, determine the sustainability of the natural landscapes of these places, calculate the number of tourists, determine the needs for quantities and types of recreational facilities, develop a model of the tourist system and environmental routes.

6. The spontaneous use of therapeutic mud leads to their depletion and microbiological pollution. Lakes need protective events and a comprehensive study of its therapeutic and recreational resources for the purpose of their rational use, in the study of the resort and recreational potential of the lake and the surrounding area.

\section{Acknowledgement}

This research was sponsored by the projects of the Ministry of Education and Science of the Republic of Kazakhstan No. AP08856374 "Assessment of the state of hydrobionts and microbiome of reservoirs in West Kazakhstan and forecast of their changes".

\section{REFERENCES}

Abaturov, B.D. \& Konyushkova, M.V. (2020). Posthvalynskaja dinamika nazemnyh jekosistem na stepnoj ravnine Severnogo Prikaspija [The post-Khvalyn dynamics of the dry land ecosystems at the steppe plain in the north of the Caspian Lowland]. Uspekhi sovremennoi biologii, 5, 494-506, (in Russian).

Adilov, V.B., Berezhnov, E.S., Bobrovnitskiy, I.P., Gusarov, I.I., Davydova, O.B., Dubovskoy, A.V., Zotova, V.I., Lvova, N.V., Novikova, O.V., Petrova, N.G., Razumov, A.N., Rogovets, A.I., Seregina, I.F., Tereshkova, L.P., Trebukhov, Ya.A., Trebukhova, T.M. \& Tupitsina, Yu.Yu. (2000). Klassifikaciya mineralnyh vod i lechebnyh gryazej dlya celej ih sertifikacii: metodicheskie ukazaniya [The Classification of Mineral Waters and Therapeutic Muds for the Purposes of Their Certification: The Guidelines], Moscow, Russian Scientific Center for Restorative Medicine and Balneology, (in Russian).

Akhmedenov, K.M. (2018). The landscape and biological diversity of salt-dome landscapes: specific features (Western Kazakhstan case study). Arabian Journal of Geosciences, 11 (15), 417. https://doi.org/10.1007/s12517-018-3725-x

Akhmedenov, K.M. (2020a). Tourist and recreational potential of the salt lakes of Western Kazakhstan. GeoJournal of Tourism and Geosites, 30 (2spl), 782-787. https://doi.org/10.30892/gtg.302spl01-505

Akhmedenov, K.M. (2020b). Assessment of the prospects of springs in Western Kazakhstan for use in religious tourism. GeoJournal of Tourism and Geosites, 31 (3), 958-965. https://doi.org/10.30892/gtg.31304-527

Argaman, E., Keesstra, S.D., Zeiliguer, A. (2012). Monitoring the impact of surface albedo on a saline lake in SW Russia. Land Degradation \& Development. 23, 4, 398-408. https://doi.org/10.1002/ldr.2155

Asubaev, B., Esmseitova, Zh. (2015). Almaty oblysyndagy Zhalanashkol kolinin emdik-sauyktyru turizmi men demalysty damytudagy manyzy [The role of Zhalanashkol lake in the development of health tourism and recreation in Almaty region], Geografiya, Biologiya, Ekologiya orta mektepte, 1 (43), 16-19 (in Kazakh).

Atkinson, D. (2007). Bolivia: The Bradt Travel Guide, Bradt Travel Guides.

Badyukova, E.N. (2020). Proishozhdenie "vrezannyh" ili slepyh delt na volgo-uralskom mezhdureche v svete novyh predstavlenij ob istorii kolebanij urovnja kaspija [The origin of the "embedded" or blind deltas in the Volga-Ural interfluve in the light of the new concept of the history of the Caspian Sea level fluctuations]. Geomorfologiya (Geomorphology RAS), 3, 71-82, (in Russian). 
Bahman, V.I., Ovsyannikova, K.A. \& Vadkovskaya, A.D. (1965). Metodika analiza lechebnyh gryazej (peloidov) [The Methodology for the Analysis of Therapeutic Muds (Peloids)], Moscow, USSR Ministry of Health, (in Russian).

Baisholanov, S.S., Pavlova, V.N., Musataeva, G.B., Gabbasova, M.S., Zhakieva, A.R., Mukanov, E.N., Limanskaya, V.B. \& Chernov, D.A. (2017). Agroklimaticheskie resursy Zapadno-Kazahstanskoj oblasti: nauchno-prikladnoj spravochnik [Agroclimatic Resources of the West Kazakhstan Region: scientific and applied reference work], Astana, (in Russian).

Belenitskaya, G.A. (2013). Proishozhdenie solej, diapirov i rassolov Mertvogo morja [Origin of salts, diapirs and brines of the Dead Sea]. Nature, Publishing House of the Russian Academy of Sciences, 8, 28-37, (in Russian).

Belgibaev, M., Zhaparova, A. (2020). Ispolzovanie ozera Shoshkaly dlya lechebnykh tselei [Use of Shoshkaly lake for medicinal purposes]. Geografiya v shkolakh i Vuzakh Kazakhstana, 1 (91), 41-43, (in Russian).

Bokuchava, N. (2009). Lechebnye grjazi Gruzii [Therapeutic muds of Georgia], Publishing House, Technical University, Tbilisi, (in Russian).

Bolshoiovic, M., Perovic, S., Perovic, A., Kastratovic, V., Roganovic, M., Potpara, Z., Martinovic, M., Pantovic, S., Milasevic, I., Djurovic, D., Slavic, V., Kosovic, M. \& Vlahovic, M. (2020). Physico-chemical characterization of Igalo Bay peloid (Montenegro) and assessment of the pollution of potentially toxic elements in the sampling area. Farmacia, 3 (68), 560-571.

Chashina, B., Ramazanova, N., Atasoy, E., Berdenov, Zh., \& Ilieş, D.C. (2020). Natural recreation potential of the West Kazakhstan region of the Republic of Kazakhstan. GeoJournal of Tourism and Geosites, 32 (4), 1355-1361. https://doi.org/10.30892/gtg.32424-580

De Almeida, C. (2018). Performative by-products: The emergence of waste reuse strategies at the Blue Lagoon. Journal of Landscape Architecture, 13, 3, 64-77, https://doi.org/10.1080/18626033.2018.1589142

Díaz Rizo, O., Barrios, Cossio J., Suárez Muñoz, M., D'Alessandro Rodríguez, K., Melián Rodríguez, C.M., González Hernández, P., Martínez-Villegas, N.V., Badawy, W., Frontasieva, M. (2018). Instrumental neutron activation analysis of peloids from main Cuban spas. Journal of radioanalytical and nuclear chemistry, 2, 1079-1087.

Dikke, G.B. (2016). Primenenie lechebnyh grjazej Mertvogo morja u zhenshhin s narusheniem reproduktivnoj funkcii na fone hronicheskogo jendometrita [The use of therapeutic mud from the Dead Sea by women with impaired reproductive function against the background of chronic endometritis]. Medical Council, 5, 124-127, (in Russian).

Doretti, L., Ferrara, D., Barison, G., Gerbasi, R. \& Battiston, G. (1992). Natural radionuclides in the muds and waters used in thermal therapy in Abano Terme, Italy. Radiation Protection Dosimetry, 1-4 (45), 175.

Doskach, A.G. (1956). About the genesis of the relief of the Volga-Ural interfluve. In Materials on Geomorphology and Paleogeography of the USSR. USSR Academy of Sciences, (In Russian).

Dzhangeldina, D., Ospanova, Zh. (2017). Turizmdi damytudagy balshykpen emdeudin alatyn orny [The role of mud therapy in the development of tourism]. Geografiya zhane tabigat, 2, 16, (in Kazakh).

Fedotchenko, A.A. (2010). Balneoterapiya i gryazelechenie (rekomendacii po lechebnomu primeneniyu): posobie dlya vrachej [The Balneotherapy and Mud Therapy (Recommendations for Therapeutic Use): The Guidelines for Medics], Irkutsk, (in Russian).

Filonec, P.P., Omarov, T.R. (1974). Ozera Severnogo, Zapadnogo i Vostochnogo Kazahstana [The Lakes of the North, West and East Kazakhstan], Leningrad, Gidrometeoizdat, (in Russian).

Fomin, I.A., Nazarova, T.V., \& Mazhitova, G.Z. (2012). Therapeutic mud of the North Kazakhstan region. Research in the field of natural sciences, 6 [Electronic resource]. (accessed in 13.09.2020), (in Russian). http://science.snauka.ru/2012/06/632

Gomes, C., Carretero, M.I., Pozo, M., Maraver, F., Cantista, P., Armijo, F., Legido, J L., Teixeira, F., Rautureau, M., \& Delgado, R. (2013). Peloids and pelotherapy: Historical evolution, classification and glossary. Applied Clay Science, 75-76, 28-38, https://doi.org/10.1016/j.clay.2013.02.008

Gomes, Cd.F (2018). Healing and edible clays: a review of basic concepts, benefits and risks. Environ Geochem Health, 40, $1739-1765$. https://doi.org/10.1007/s10653-016-9903-4

Gomes, CSF, Silva, JBP, Gomes, JHC. (2015). Natural peloids versus designed and engineered peloids. Bol Soc Esp Hidrol Med, 30 (1), 1536. https://doi.org/10.23853/bsehm.2017.0377

Gupta, D., Bhatia, D., Dave, V., Sutariya, V., Gupta, S.V. (2018). Salts of Therapeutic Agents: Chemical, Physicochemical, and Biological Considerations. Molecules, 23, 1719. https://doi.org/10.3390/molecules23071719

Ivanov, V.V. (1951). Fiziko-geograficheskaja harakteristika rek Bol'shoj i Malyj Uzen [Physical and geographical characteristics of the rivers of the Bolshoi and Small Uzeney]. Izvestiya Vsesoyuznogo geograficheskogo obshchestva, 6, 541-549, (in Russian).

Kalioujnaia, I.J., Kurinova, A.N.\& Surganov, V.I. (2019). Rol prirodnyh kurortno-rekreacionnyh faktorov v lechebno-ozdorovitelnoj deyatelnosti sanatoriya Elton [The importance of natural recreation and spa-factors for medical-therapeutic activities of the Elton Resort]. Estestvennye i tehnicheskie nauki, 7 (133), 94-101, (in Russian).

Kamensky, G.N., Gourmanov, I.V., Bogdanov, G.Ya., Gurkina, N.F., Raspopov, M.P., Yartseva, E.Ya. (1960). Gruntovye vody Prikaspijskoj nizmennosti $i$ ih rezhim $v$ predelah Volgo-Ural'skogo mezhdurech'ja [Groundwater of the Caspian lowland and its regime within the Volga-Ural interfluve], Moscow, Publishing House of the USSR Academy of Sciences, (in Russian).

Kan, S.M., Kalugin, O.A., \& Iskanderov, R.R. (2019). Znachenie lechebnyh grjazej mestorozhdenija Arasan-Kundyzdy dlja razvitija peloidoterapii v Kazahstane [The importance of therapeutic muds of the Arasan-Kundyzdy deposit for the development of peloid therapy in Kazakhstan]. Problems of Balneology, Physiotherapy, and Exercise Therapy, 96 (6), 46-49, (in Russian). https://doi.org/10.17116/kurort20199606146

Karakaya, M. Ç., Karakaya, N., Sarığlan, Ş., Koral, M. (2010). Some properties of thermal muds of some spas in Turkey. Applied Clay Science, 48, 3, 531-537, https://doi.org/10.1016/j.clay.2010.02.005

Khalelova, R. A., Kaliouzhnaya, I.J.\& Golubeva, E.I. (2020). Bal'neologicheskie svojstva peloidov solenyh ozer (ozera Bol'shoj Sor i Sorkol) $v$ Zapadnom Kazahstane [The balneological properties of peloids of salt lakes (Bolshoy Sor lake and Sorkol lake) in West Kazakhstan]. Regional Environmental Issues, 4, 77-84, (in Russian). https://doi.org/10.24411/1728-323X-2020-14077

Kopyl, I.V., Nikolaev, V.A. (1984). Fiziko-geograficheskoe rajonirovanie Prikaspijskoj nizmennosti po materialam kosmicheskoj semki [The Physical and Geographical Classification of the Caspian Lowland Based on the Satellite Imagery]. Vestnik Mosk, un-ta. Ser. 5, Geogr., 1, 65-70, (in Russian).

Koshim, A.G., Sergeyeva, A.M., Saparov, K.T., Berdibayeva, S.K., \& Assylbekova, A.A. (2020). Underground mosques of Mangystau as the objects of religious tourism. GeoJournal of Tourism and Geosites, 34 (1), 33-41. https://doi.org/10.30892/gtg.34105-616

Kotov, S., Kotova, I. \& Kayukova E. (2019). Geologicheskij kontrol' i vlijanie chelovecheskogo obshhestva na sostav peloidov sovremennyh solenyh ozer (pribrezhnye zony Chernogo, Azovskogo i Mertvogo morej) [Geological controls and the impact of human society on the composition of peloids of present-day salt lakes (coastal zones of the Black, Azov, and Dead seas)]. Journal of Coastal Conservation, 4 (23), 843-855, (in Russian). 
Kotova, I.K., Kayukova, E.P., Mordukhai-Boltovskaya, L.V., Platonova, N.V.\& Kotov, S.R. (2015). Shema formirovanija sostava ilovoj grjazi Mertvogo morja i solenyh ozer Kryma [Pattern of the composition formation of oozy mud from the Dead Sea and salt lakes of Crimea]. Saint Petersburg State University Bulletin, 2, 85-106, (in Russian).

Kovtun, M. (2017). Dead Sea Gifts. Raw materials and packaging for cosmetics, perfumes and household chemicals, 5, https://cosmeticindustry.com/en/dary-mertvogo-morya.html

Lopatina, A.B. (2016). Himicheskij sostav Mertvogo morja (Izrail’) [The chemical composition of the Dead Sea (Israel)]. Scientific bulletin, 1, 215-221, (in Russian). http://ucom.ru/doc/nv.2016.01.215.pdf

Malkhazova, S.M., Ezerova, L.V., Kotova, T.V., Krainov, V.N., Leonova, N.B., Miklyaeva, I.M., Orlov, D.S., Pestina, P.V., Puzanova, T. A., Ryabova, N.V., Starikov, S.M., Surkova, G.V., \& Shartova, N.V. (2019). Gryazevye istochniki (peloidy). Mediko-geograficheskij atlas Rossii "Celebnye istochniki i rasteniya" [The Mud Sources (Peloids). Medical-Geographical Atlas of Russia "Remedial sources and plants"], Moscow, Moscow State University, (in Russian).

Ma'or, Z., Henis, Y., Alon, Y., Orlov, E., Sørensen, KB., Oren, A. (2005). Antimicrobial properties of Dead Sea black mineral mud. International Society of Dermatology. https://doi.org/10.1111/j.1365-4632.2005.02621.x

Medeu, A.R., Akiyanova, F.Zh. \& Blagoveshenski, V.P. (2010). Natsional'nyy Atlas Respubliki Kazakhstan. Tom 1. Prirodnyye usloviya i resursy [National Atlas of the Republic of Kazakhstan. Vol. 1: Natural Conditions and Resources], Almaty, (in Russian).

Mikheeva, L.S., Trebukhov, J.A. (1987). Kriterii ocenki kachestva lechebnyh gryazej pri ih razvedke, ispolzovanii $i$ ohrane: Metodicheskie ukazaniya [The Criteria for Assessing the Quality of Therapeutic Muds During Their Exploration, Use and Protection: The Guidelines], Moscow, (in Russian).

Mikheeva L.S., Trebukhov Ya. A. (1975). Rekomendacii po izucheniyu mestorozhdenij lechebnyh gryazej [The Recommendations for the Study of Therapeutic Mud Deposits], Moscow, USSR Ministry of Health, (in Russian).

Muradov, S.V. (2014) Ekologicheskie i mikrobiologicheskie osobennosti formirovaniya i sostoyaniya mestorozhdenij lechebnyh gryazej: dis. ... d-ra biol. nauk: 03.02.08 [The Ecological and Microbiological Features of Forming and Condition of Therapeutic Muds Deposits: Dr. in Biology Paper], Petropavlovsk-Kamchatskij, (in Russian).

Myazina, N.G. (2013). Resursy ozer Prikaspijskoj vpadiny i ee obramleniya [The Resources of the Lakes of the Caspian Depression and its surroundings]. Vestnik OGU, 9 (158), 115-118, (in Russian).

Nikanorov, A.M. (2001). Gidrohimija [Hydrochemistry], St. Petersburg, Gidrometeoizdat, (in Russian).

Nissenbaum, A., Rullkötter, J. \& Yechieli, Y. (2002). Are the Curative Properties of 'Black Mud' from the Dead Sea Due to the Presence of Bitumen (Asphalt) or Other Types of Organic Matter? Environmental Geochemistry and Health, 24, 327-335. https://doi.org/10.1023/A:1020559717754

Olefirenko, V.T. (1986). Vodoteplolechenie [The Heat-Water Therapy], Moscow, Medicina, (in Russian).

Ozer, Z., Akpinar, M., \& Akcay, M. (1987). Investigation of some chemical and biological properties of Kangal (Sivas) Fishy Hot Springs. Fen Bilimleri Dergisi, 5, 1-34.

Radulescu, C., Dulama I.D., Stihi, C., Ionita, I., Chilian A., C. Necula, \& Chelarescu E.D. (2014). Determination of heavy metal levels in water and therapeutic mud by Atomic Absorption Spectrometry. Romanian Journal in Physics, 59, 9-10, 1057-1058.

Sdykov, M.N., Bisembaev, A.A., Gutsalov, S.Yu., Beknazarov, R.A. Ernazarov, Zh.T., Zhubanov, A.A., Ramazanov, S.K., Zhusupkaliev, T.T., Mergaliev, R.S., Maryksin, D.V., Amangaliev, G.Z. \& Utepbaev, U.A. (2010). Svod pamjatnikov prirodnogo i istoriko-kul'turnogo nasledija Zapadno-Kazahstanskoj oblasti [The collection of monuments of natural and historical and cultural heritage of the West Kazakhstan region], Almaty, Aruna, (in Russian).

Sidorenko, A.V. (1970). Geologiya SSSR. Tom XXI. Zapadnyi Kazakhstan. Chast 'I. Geologicheskoe opisanie. Kniga 1 [Geology of the USSR. Vol. XXI. Western Kazakhstan. Part I. Geological description. Book 1], Moscow, Nedra, (in Russian).

Solonenko, A.N. (2015). Composition of organic matters and enzymatic activity of peloids of hyperhaline water bodies of the north-western coast of the Sea of Azov (Ukraine). Hydrobiological journal, 6 (51), 22-27.

Sotnikov, A.V., Makkaveev, A.A.\&Sydykov Zh.S. (1971). Gidrogeologiya SSSR. Tom. XXXV: Zapadnyj Kazahstan [Hydrogeology of the USSR. Vol. XXXV: West Kazakhstan], Moscow, Nedra, (in Russian).

Tokpanov, Ye.A. (2016). Gidromineral'nye rekreacionnye resursy ozera Zhalanashkol' [Hydromineral recreational resources of Zhalanashkol lake], KazNU Bulletin. Geography, series, 2, 305-309, (in Russian).

Tserenkhand, B. \& Badnainyambuu, Z. (2016). Composition and classification of some peloids in the western region of Mongolia. Journal of Chemical Technology and Metallurgy, 51, 5, 570-576.

Tserenpil, Sh., Dolmaa, G. \& Voronkov, M.G. (2010). Organic matters in healing muds from Mongolia. Applied Clay Science, 49, 1-2, 5563, https://doi.org/10.1016/j.clay.2010.04.002

Wendt, J.A. (2020). Directions and areas of tourism research in Kazakhstan. GeoJournal of Tourism and Geosites, 32 (4), $1418-1424$. https://doi.org/10.30892/gtg.32433-589

Zhuravleva, L.B. (2008). Uchebnoe posobie po discipline "Kurortnoe delo s osnovami kurortologii" [The Manual on the "Health Resort Business with the Fundamentals of Balneology" Discipline], Sochi: Sochinskij gos. un-t turizma i kurortnogo dela, (in Russian).

Article history: Received: 06.02.2021 Revised: 17.04.2021 Accepted: 11.06.2021 Available online: 30.06 .2021 